\title{
Selected aspects of corporate social responsibility in maritime freight services on the example of selected courier companies
}

\author{
Agnieszka Budziewicz-Guźlecka' ${ }^{1}$ Anna Drab-Kurowska²
}

\begin{abstract}
The aim of the article is to present the activities of corporate social responsibility in the CEP industry, with particular emphasis on maritime freight services. The article will present good practices and environmental activities proposed by the leaders of the CEP industry. An example may be the new "green services" of sea freight, which allow for reduction of $\mathrm{CO} 2$ emissions. The article puts forward the following research hypothesis - Raising awareness in the CSR area in the CEP industry will allow the implementation of environmental activities. In reference to the assumed goal and the hypothesis adopted in the article, the following research question was posed - what specific CSR implementation tools should be adopted by the CEP industry to actively shape environmental activities in maritime freight services? In an attempt to answer the question, the article first addressed the aspects of corporate social responsibility at CSR 3.0 level. Next, the focus was on presenting the results of the analysis of the maritime freight services offered by the leaders of the CEP industry. The following research methods were used in the article: method of critical analysis of literature, method of observing the proceedings of the entities examined, logical inference method, method of analysis and synthesis. The key element of the article is the presentation of proposals for actions aimed at intensifying activities strengthening maritime transport services through activities in the area of CSR.
\end{abstract}

\section{The essence of CSR}

Enterprises, including CEP market enterprises, are increasingly aware that successful operation on the market requires the creation of a cooperation network including not only customers but also employees, suppliers or intermediaries. Corporate Social Responsibility (CSR) is an essential and increasingly important topic for many organizations. So far, there is neither a general definition of this concept nor a universal concept of Corporate Social Responsibility in the literature. Most definitions describe it as a concept of integrating social and environmental issues into their business activities and their stakeholders on a voluntary basis; acting responsibly towards various social, environmental and economic pressures in order to respond to the expectations of the various stakeholders they interact with, such as employees, shareholders, investors, consumers, public authorities and non-

\footnotetext{
${ }^{1}$ University of Szczecin, Poland, agnieszka.budziewicz@wzieu.pl

${ }^{2}$ University of Szczecin, Poland, anna.drab@wzieu.pl
} 
governmental organizations (NGOs). It is worth stressing, however, that there is a lack of one primary definition of Social Responsibility.

Business responsibility, as an ethical value consisting in incurring the

consequences of the company's activities, has been discussed in the world for many years. Some researchers see CSR sources in the business ethics and regard as its beginnings works such as Leo XIII's encyclical Rerum Novarum of 1891, The Fundamentals of Business Ethics, published in the USA in 1926, and a later work - Social Responsibilities of the Businessman, published in 1953. [1]

The CSR idea evolved into a debate about business society in the 1920s. During the crisis and the Second World War, the debate fell silent and reappeared in the 1950s. The debate on CSR focused on the obligations of enterprises to society. However, defining what is the main message in the CSR concept was considered too complex and vague to be possibly indicated for the management teams of organizations. In the 1970s it was proposed that CSR could be considered as a "social reaction of an enterprise" to the expectations and requirements of society towards companies [2]. Freeman introduced the perspective of stakeholders as a way to manage organizations. He pointed out that external stakeholders should be reckoned with, but not only traditionally understood (clients, suppliers), but also non-market stakeholders, such as the media or local authorities [3]. Then, in his article, Frederick outlined a conceptual transition from the philosophical and ethical concept of CSR to the action-oriented concept of managerial corporate social responsibility in relation to social pressure [4]. Therefore, society should have social responsibilities, and then management teams should respond to social needs.

As a result, CSR has moved from ideology to reality, and many consider it absolutely necessary that organizations should play an important role in society and apply social, ethical, legal and responsible standards to their enterprises [5]. On the other hand, Young defines CSR as a strategic and long-term approach, based on the principles of social dialogue, transparent relationships and the search for solutions that are beneficial to everyone; it also means achieving lasting profit while wisely shaping relationships with all stakeholders. He also points out that it is also conducting business in a way that takes into account ethical values, law, respect for employees, society and the natural environment, as well as contributing to sustainable development through cooperation with stakeholders in order to improve the quality of life of all citizens [6]. CSR is a process aimed at taking over responsibility for the company's activities and encouraging a positive impact through its activities on the environment, consumers, employees (creating conditions for development and access to the best knowledge transfer techniques [7], communities, stakeholders and all other members of the public sphere, who may also be considered as stakeholders.

On the example of CEP market entities, it can be indicated that, it can be pointed out that CSR evolved from CSR through CSR 2.0 up to CSR 3.0. CSR 2.0 assumes that relations with the local community and other stakeholders are built on the basis of cooperation and partnership, which increases the chances of a positive solution to many global problems. In accordance with CSR 2.0, business creates value by directing its innovation and creativity to solving burning social and ecological problems on a global scale [8].

In turn, the concept of CSR 3.0 is based on a systemic approach to corporate social responsibility and inclusion of national as well as international law, economy and civil society in its activities.

The CSR 3.0 concept is characterized by the following features [9]:

- social cooperation - changes are the driving force,

- proactive management - a holistic CSR approach in all departments of the organization,

- dialogue with a network of stakeholders - strengthening the position of the company, local communities and the country, 
- systemic approach to CSR by the state, law, economy, civil society - a global approach to problems and local action.

The CEP market players are involved in corporate social responsibility (CSR), mainly because they can benefit from such involvement. As a result, various NGOs have started developing CSR reporting models or frameworks, seeking inspiration in ISO 14001 (International Organization for Standardization), World Resources Institute (WRI) and Global Reporting Initiative (GRI). With regard to empirical research on CSR, three types of empirical research characterize the research in this field. The first concerns 'descriptive research', which is a report on the nature and scope of CSR with some comparisons of countries and periods. The second concerns 'explanatory research', which focuses on potential determinants of social and environmental reporting. The third is interested in the "impact of social and environmental information" on various users, mainly on market reactions. [10]

In this context, the awareness and social and ethical involvement of society have increased. Treating the environmental protection and interaction with the environment in the convention of a value chain and managing it in the aspect of creating added value is a promising concept. At the same time, various motives for undertaking environmental initiatives in the value chain are indicated [11]. CSR is defined as caring for the well-being of others and the environment in order to create value for the business. CSR manifests itself in operational strategies and practices that it develops. [12]). This idea draws attention to non-economic aspects of enterprises' activities, which should care not only for their own interest but also take into account the impact they have on the environment and the generally understood social good.

Social Responsibility can adopt the following levels, which are also noticed on the CEP market:

- CSR level imposed in some way by applicable law,

- CSR level forced on the organization by strong social pressure exerted by external stakeholders,

- A voluntary CSR level implemented by organizations that feel responsible due to their sense of place in society.

The fact that there is no understanding of the concept of CSR at the international level complicates both theoretical development of the concept and the implementation and measurement of success at the company level. This fact is particularly important considering the fundamental change in the debate on CSR: today management is not so much about whether CSR activities should take place, but rather how they should be conducted. The conducted analysis of CEP market entities has shown that the leading entities of this market can be good examples of activities carried out in the area of CSR. These entities provide sea freight services, which are the driving force of the blue economy. It should be emphasized that the blue economy is characterized by enormous potential, conducive to economic growth.

\section{Trends on the market of maritime transport services in the context of sustainable development}

The idea of sustainable development is a concept that aims to guide broadly understood growth and socio-economic development of the European Union countries. It is indicated that the maritime economy has a chance to be one of the engines of economic growth in Europe over the next dozen or so years. This perspective is drawn by the European Union, seeing in the blue economy the potential that will improve the economic situation of 
member states, including Poland. Blue growth should take place in conditions of sustainable development, which means improvement of economic results with simultaneous care for the environment, employees and local communities (http://ec.europa.eu/growth/industry/corporate-social-responsibility/). It should be pointed out that seafaring is one of the oldest forms of transport. Over the centuries, both ports and ships have evolved to increase their transport capabilities and reduce the associated costs. The largest technological leap in this area was noted in the 20th century. In particular, the digitization of services has improved port efficiency, and new technologies used in the construction of larger container vessels significantly increased the number of transported goods. [13]

The data from the 2013 Maritime Transport Review show that $80 \%$ of global trade takes place by sea ((Review of maritime transport 2013). The globalization of economic activity contributes to the increased demand for global transport services. This trend is conducive to the development of maritime transport, especially its commodity branch. This is mainly due to the lower price of intercontinental transport as well as the higher load capacity of ships compared to other modes of transport. It should be emphasized that sea transport in relation to the payload criterion offers the largest transport capacity. At the turn of $1990-2013$, there was a $58.31 \%$ increase in the volume of transport in international maritime trade. This testifies first of all to the technological and organizational development of seaports and the modernization of ships.

In addition, it is necessary to refer to global demand forecasts for cargo transport in individual transport branches in Poland by 2030.

Table 1. Forecast of global demand for cargo transport by 2030 .

\begin{tabular}{|c|c|c|c|}
\hline \multirow{2}{*}{$\begin{array}{l}\text { Branch of } \\
\text { transport }\end{array}$} & \multicolumn{3}{|c|}{ Years } \\
\hline & 2015 & 2020 & 2030 \\
\hline \multicolumn{4}{|c|}{ Transport in million tons } \\
\hline Railway & 211 & 225 & 261 \\
\hline Automobile & 1643 & 1800 & 2075 \\
\hline $\begin{array}{l}\text { Inland } \\
\text { waterway }\end{array}$ & 6.1 & 8.5 & 14 \\
\hline Piping & 54 & 56 & 66 \\
\hline Maritime & 52 & 60 & 81 \\
\hline Air & 0.1 & 0.1 & 0.2 \\
\hline \multicolumn{4}{|c|}{ Transport in billion tkm } \\
\hline Railway & 46 & 50 & 62 \\
\hline Automobile & 279 & 321 & 405 \\
\hline $\begin{array}{l}\text { Inland } \\
\text { waterway }\end{array}$ & 1.4 & 1.6 & 3.2 \\
\hline Piping & 23 & 23 & 26 \\
\hline Maritime & 110 & 123 & 159 \\
\hline Air & 0.2 & 0.3 & 0.6 \\
\hline
\end{tabular}

Source: [14]

Sea transport is considered one of the most dynamically developing. It is estimated that in the years 2015-2030 transport will increase from about $44 \%$ to $56 \%$, depending on how the transport is measured. This perspective is reflected in the behaviour of the CEP market entities. Sea freight services are one of the key services offered by the leading CEP market operators. The increase in interest results, inter alia, from the need to reduce transaction costs (Wilmsmeier, Hoffmann, Sanchez, 2006), as well as from the development of international trade. International business and trade are largely dependent on global shipping, which as part of the logistics chain determines the effectiveness of global trade. 
Factors affecting both the development and functioning of maritime transport are [15]: - economic conditions,

- financial conditions,

- current maritime policy,

- rules for the protection of the marine environment,

- innovativeness of transport processes.

In connection with the intensive development of transport in the field of maritime transport, in 2016 the European Commission published two executive regulations ${ }^{3}$ introducing tools for monitoring and reporting fuel consumption as well as carbon dioxide (CO2) emissions by maritime transport. These regulations came into force on November 25, 2016. Both legal acts were issued in order to implement the law previously adopted by the European Union, which is Regulation of the European Parliament and of the Council (EU) 2015/757 of 29 April 2015 on monitoring, reporting and verification of carbon dioxide emissions from maritime transport, and amendments of Directive 2009/16 / EC. Both were also published in order to introduce uniform conditions for the implementation of legal regulations resulting from Regulation (EU) 2015/757 in all Member States. In accordance with EU climate and energy legislation, all sectors of the economy, including international shipping, should contribute to such reduction of emissions. It was estimated that total $\mathrm{CO} 2$ emissions related to European maritime transport (taking into account internal EU routes, cruises to the EU and cruises made from the EU territory) in 2010 amounted to about $180 \mathrm{Mt} \mathrm{CO} 2$. The EU also forecasts that $\mathrm{CO} 2$ emissions from European maritime transport (taking into account the same assumptions regarding internal EU routes, cruises to the EU and cruises from the EU) will reach $210 \mathrm{Mt}$ in 2020 (+8\% compared to 2005 level). r.), $223 \mathrm{Mt}$ in 2030 $(+15 \%$ in relation to the level of 2005) and $271 \mathrm{Mt}$ in $2050(+39 \%$ in relation to the level of 2005).

Undertaking activities aimed at reducing pollutions emissions is reflected in the activities for corporate social responsibility. In the activities of all entities servicing sea transport, wide-ranging actions aimed at reducing pollution emissions can be observed. Some of these entities are already well advanced in these activities, while some on the principle of "good examples" of leading entities strive to introduce ecological solutions to their operations. The article pays special attention to the entities of the CEP market.

\footnotetext{
3 1. Commission Executive Regulation (EU) 2016/1927 of 4 November 2016 on templates for monitoring plans, emission reports and compliance documents in accordance with Regulation (EU) 2015/757 of the European Parliament and of the Commission on monitoring and reporting and verification of carbon dioxide emissions from maritime transport.

2. Commission Executive Regulation (EU) 2016/1928 of 4 November 2016 on the determination of cargo carried with respect to the category of ships other than passenger ships, ro-ro vessels and container ships, in accordance with the Regulation of the European Parliament and of the Council (EU) 2015/757 on the monitoring, reporting and verification of carbon dioxide emissions from maritime transport. In December 2010, the parties to the United Nations Framework Convention on Climate Change recognized that global warming could not exceed pre-industrial temperatures by more than $2^{\circ} \mathrm{C}$. This is necessary to limit the negative impact of human activities on the climate. This long-term goal requires a reduction of global greenhouse gas emissions by 2050 by at least $50 \%$ below the 1990 level. By 2050, developed countries should reduce their emissions by $80-95 \%$.

In July 2011, the International Maritime Organization (IMO) adopted operational and technical measures, in particular, the construction energy efficiency indicator for new vessels and the ship energy efficiency management plan (SEEMP), which were to provide an improvement in the reduction of greenhouse gas emissions.

The EU is strongly committed to achieving the objective of combating climate change by limiting global warming to $2^{\circ} \mathrm{C}$. Consequently, one of the key objectives of the Europe 2020 strategy for employment and smart, sustainable and inclusive economic growth is to reduce greenhouse gas emissions by $20 \%$ below 1990 levels by 2020 or, if specific conditions, by $30 \%$.
} 


\section{CSR on the example of sea freight services in the CEP sector}

The idea of sustainable development and ecological solutions is part of the concept of corporate social responsibility (CSR) applied more and more often by enterprises operating in various branches of the economy, also in the CEP industry.

As previously emphasized, along with the development of maritime freight services, there is an intense increase in activities for social responsibility in the CEP industry. Leading, foreign industry leaders show great interest in the subject of CSR. This interest is not limited to the traditional look at corporate social responsibility (CSR 1.0). The largest entities of the CEP market not only noticed the possibility of using the advanced CSR level but also started a series of activities consistent with the next stage of responsibility - CSR 2.0. The advanced level of corporate social responsibility in the CEP sector is reflected in strategies, good practices of enterprises and the trendsetting. An example of developing a modern CSR strategy is the DPD Group proposal - DrivingChange strategy. In the strategy announced in February 2016, the company focuses on four key areas of its business profile:

- neutral for the environment;

- friendly city logistics;

- innovative entrepreneurship;

- closer to the community.

Each of the areas proposed by the company has a defined goal and measures used to achieve it, which at the same time become good practices of the organization. An example of this is the action to reduce $\mathrm{CO} 2$ emissions and the measures taken for its implementation - gradual modernization of the fleet of their vehicles so that ultimately they would be maximum 5-year-old vehicles. In addition to standard practices characteristic of transport companies, e.g. route optimization, this entity is involved in solving global problems, emphasizing the importance of renewable energy sources through the purchase of carbon credits. In its operations, DPD also focuses on creating a new value for society. Practices created as part of "friendly urban logistics" are to have a positive impact on the environment (reduction of pollution in city centres, reduction of congestion), but above all to bring a social benefit. An example is creating points for sending and receiving parcels. In addition, the entity also focuses on the Predict service, thanks to which it is possible to flexibly manage the time of delivery, which eliminates the phenomenon of empty runs. The DrivingChange strategy also means stakeholder-oriented activities; in line with the CSR 2.0 assumptions, the company builds a bond with its stakeholders. These activities apply to both company employees and partners. In the case of employees, DPD Group undertakes a number of activities aimed at investing in people and designs a number of incentive programs. DPD also supports local communities. However, particular attention should be paid to the ecological model of office management adopted in the company, based on reducing water and energy consumption as well as waste recycling. It is clearly visible that DPD Group is undertaking a series of activities in the area of CSR, however, referring to maritime freight services, DPD in its CSR strategy does not clearly indicate actions targeted in this area. It is necessary to strengthen this direction, all the more that from year to year the share of maritime freight services is increasing in the activity of this operator.

Another entity in the CEP sector is FedEx. As part of a comprehensive international freight forwarding program, FedEx Trade Networks offers sea freight services connecting North America, Latin America, the Asia-Pacific region, Europe and the Middle East ${ }^{4}$. Taking advantage of the possibilities of regional sea terminals, wide opportunities to sail

\footnotetext{
${ }^{4}$ Full container load transports (FCL). Less than container load transports (LCL) - LCL Economy service, FedEx ${ }^{\circledR}$ International DirectDistribution service and LCL Direct service for urgent shipments.
} 
out each week, and privileged relationships with many shipowners, it maximizes transport flexibility while maintaining the right level of costs; all this in the context of activities for corporate social responsibility, through the EarthSmart program (www.fedex.com). This program expresses FedEx's commitment to environmental protection. It is a set of initiatives offering specific business and environmental benefits. EarthSmart consists of three pillars:

- EarthSmart Innovations - FedEx services and assets such as trucks and facilities that meet stringent standards in the field of innovation and environmental protection. Examples of EarthSmart FedEx global solutions include electrically powered tricycles that operate in Paris, hybrid trucks and all the electric vans that FedEx operates in major urban centres such as Paris and London, as well as an automated electronic document sending tool (ETD).

- EarthSmart Outreach - by running many global and local philanthropic projects, FedEx strengthens its efforts to create cleaner, healthier and more efficient living conditions by supporting environmentally friendly transport, green urban spaces and resilient ecosystems. FedEx supports sustainable development projects through its employees, allocating their time and skills to support important issues.

- EarthSmart@ Work - programs that engage employees in environmental matters and help them make a significant contribution to sustainable environmental development.

In addition, as part of CSR activities, FedEx declares that the target in the form of fuel savings was exceeded by $30 \%$ approximately 5 years before the set date. The company has achieved such ratios thanks to a strategy based on three categories of activities: reduction of total transport costs through route optimization, an introduction of more fuel-efficient vehicles, expansion of the fleet with vehicles powered by alternative fuels.

The entity that can be considered as the leading among the entities of the CEP sector in the field of sea freight is DP DHL Group. DHL Group conducts very extensive activities in the field of good practices and pro-environmental activities. It is these company activities that are rewarded and highly rated in both CSR rankings and practices in the field of "green logistics". This is not the only plane that distinguishes the company from the point of view of social responsibility. In addition to the monitored and improved CSR strategy and reporting of its activities, the company focuses on creating a new value aimed at persuading the CEP sector to act in the area of responsible logistics. A report was prepared to accelerate the implementation of the concept of sustainable development in the CEP industry, which again points to the advanced CSR level of the organization. There were indicated 15 possibilities of applying the concept of corporate social responsibility. DHL focuses on trends aimed at introducing activities related to circulation economy, increasing the availability of transport services, as well as achieving responsible trade and production. According to the report, these changes are possible through appropriate global management, relations with stakeholders and becoming aware of the impact that logistics companies have on society, the economy and the environment. DHL also gives examples of good practices. By focusing on the circular economy, the use of vehicles with so-called "Flexible interior" is predicted. This type of solution is aimed at adjusting the load space, which is divided into two parts: with consignments for delivery and with a place for storing secondary raw materials. The size of individual parts is to change during delivery, so as to fully use the cargo space both when delivering shipments and returning to the base. Thus, DHL creates a new value, solutions that are meant to be a response to global problems. Another of them is the possibilities associated with packaging. Here, the key is not only the use of degradable materials but also a change in approach to them. One of the DHL group companies, DHL Global Forwarding was the first global company in the logistics industry that set the goal of quantitative reduction of $\mathrm{CO} 2$ emissions. Thanks to the optimization of 
the means of transport by 2020 , the company intends to reduce the $\mathrm{CO} 2$ emissions resulting from operations by $30 \%$ compared to the level from 2007 [16]. DHL Global Forwarding is also the first freight forwarder in the industry to launch a green service with reduced $\mathrm{CO} 2$ emissions for sea freight. The Green Danmar service - offered by Danmar Lines NVOCC (Non-Vessel Operating Common Carrier) - allows customers to choose a carrier that emits 5 percent less carbon dioxide than the industry average. In addition, the customer may choose to combine this service with a DHL compensation solution and transport his shipment in a carbon-free way. Thanks to this, only over the last few years DHL Global Forwarding has reduced carbon dioxide emissions in sea freight by more than 40 percent.

The interest in creating more and more good practices in these areas is in line with current trends of business development in terms of sustainable development (Turoń, Golba, Czech 2015). Although these investments may seem costly and long-term, companies realize that they contribute not only to improving the functioning of their environment but also to investing in their own organization and promotion (Turon 2015). In turn, the occurrence of an increasing number of good practices in the organizational area proves their real impact on the organization and gives the opportunity to improve it. Corporate social responsibility also brings benefits to the company related to human resources management. Research shows that the CSR policy implemented in companies in the field of work practices is manifested in the employees' greater involvement and satisfaction with the work. The aspect of increasing the organization's innovativeness should also be pointed out. By designing their own good practices, companies often go a step further, creating a new, innovative value for society, the environment, but often also for the economy. An example of this may be activities of the DHL logistics company, which, apart from developing its own CSR strategies, also publishes reports on sustainable development or future trends. In the latest report "Logistic Trend Radar DHL 2016", the company presents a set of 26 trends that can be used in the logistics industry in the near future. Of the 26 trends, 14 are activities that focus on social and business aspects that fully take into account the principles of sustainable development. The important fact is that these are the development guidelines for the entire logistics industry, not just the publication associated with the brand's activities. DHL thus creates a new value, but also provides directions for other players in the logistics industry [17].

Summarizing activities in the area of CSR, it should be pointed out that there are clear tendencies that describe CSR areas, as shown in Figure 1.
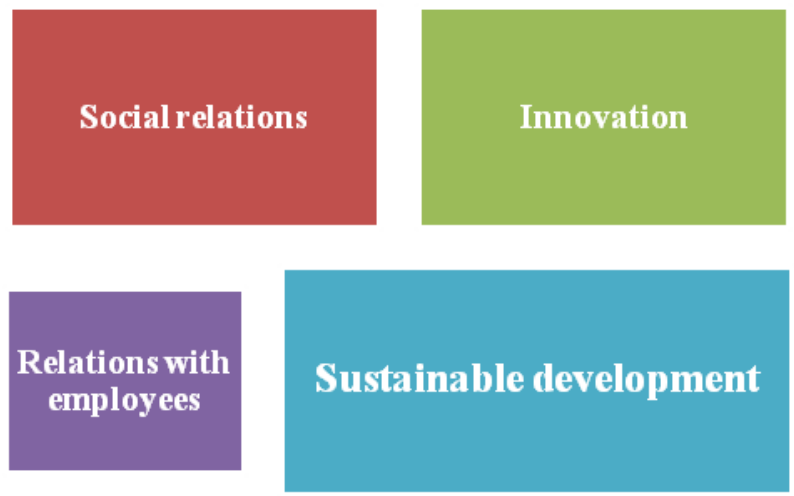

Fig. 1 CSR areas.

Source: Own study 
From the point of view of the maritime economy, the most important area of CSR is sustainable development. In the case of the analyzed sector, with particular reference to sea freight, it is clearly visible that CEP market entities carry out a series of activities which, however, are not always oriented towards maritime freight services. A clear focus on shaping CSR activities for these services is necessary. Below (Figure 2), there is a model for strengthening CSR activities in the field of sea freight for the CEP industry.

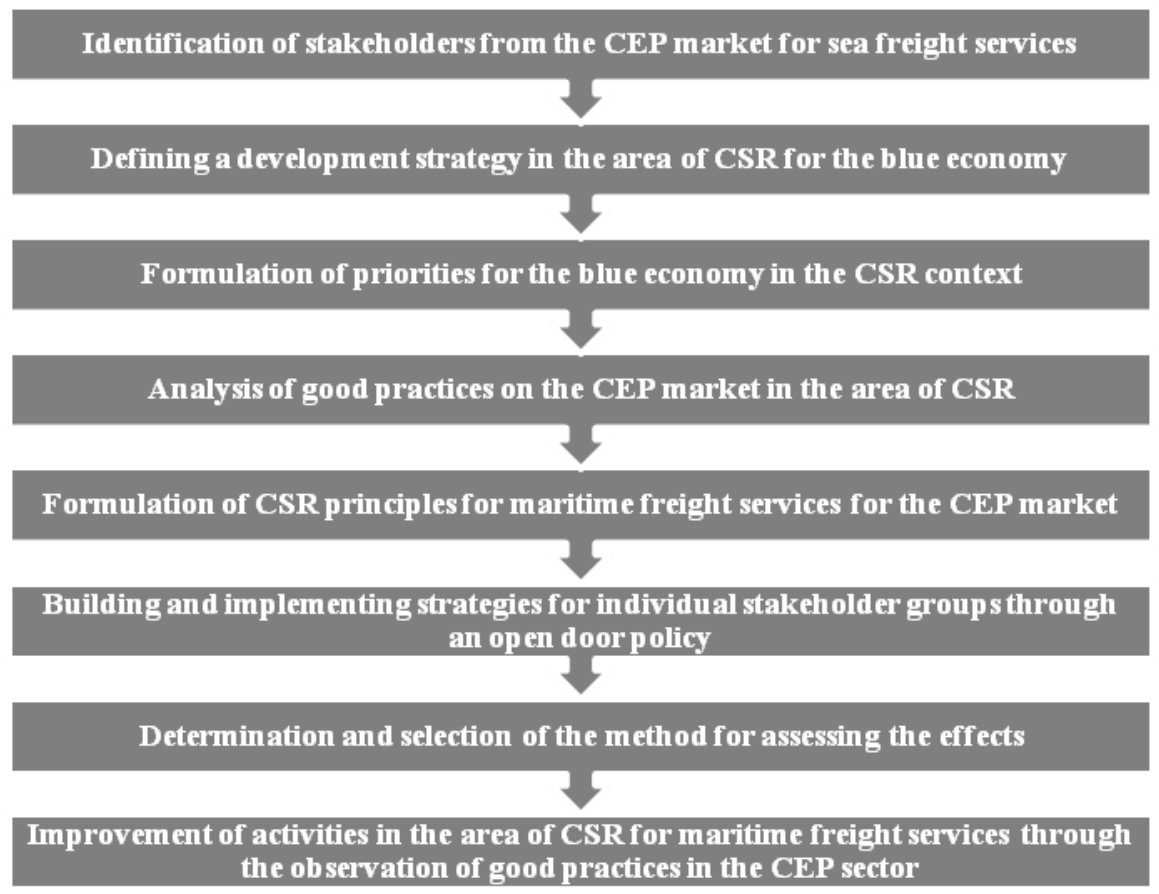

Fig. 2 Model strengthening CSR activities in the area of sea freight. Source: own study.

The starting point should be an accurate identification of stakeholders. The analysis should concern all entities: clients, institutions, organizations, offices that may influence the company representing the CEP market as well as those who are influenced by its activities. A precise definition of the groups to which actions can be directed alongside with their needs and expectations is required. Correct identification of stakeholders, as well as dialogue with them, contribute to the more effective implementation of the objectives set in the social responsibility strategy.

The next stage should be defining the strategy in the area of CSR 3.0 for a sustainable 'blue economy'. The strategy should include:

- integration activities implemented through the active and effective involvement of all interested parties,

- clear, transparent and responsible actions. This will be conducive to taking steps also in the case of adverse unplanned effects,

- holistic, cross-sectoral and long-term activities. All decisions should be made on the basis of current and future consequences, in the context of values, costs and benefits for stakeholders,

- innovative activities taking into account the natural possibilities of the environment. 
The next stage should be formulation and specification of priorities for the blue economy, with particular emphasis on CSR.

The next step should be to analyze the activities that yielded concrete, positive results, and which contain some innovation potential, durable, and that can be repetitive, applicable to similar conditions elsewhere by other entities. The provision of good CSR practice is the promotion of the organization; it is a sense of satisfaction that the effects of the work performed can serve others. Such analysis allows for the use of good practices among other CEP market organizations.

The formulation of CSR principles for sea freight services for the CEP market is another stage that details the organization's conduct.

Then, consistently strategies for all stakeholder groups should be built and implemented. An open door policy with a priority emphasis on sustainable development as well as corporate social responsibility can be used.

The next element should be the determination and selection of the method for assessing the effects. The obtained effects of a given action should exceed the costs incurred for its implementation. At the same time, what is effective must refer to the assumed goals of the action. However, it should be remembered that CSR aspects are very difficult to measure and new methods should be followed, but first and foremost, good practices in this field should be analyzed. The last but in fact, the continuous stage should be the endless improvement of activities in the area of corporate social responsibility for maritime freight services.

\section{Summary}

CSR is a concept that indicates the directions of development of entities in the conditions of sustainable development. The article presents specific solutions for the CEP market entities, which constitute a significant support for the blue economy by providing maritime freight services. The article analyzes the leading entities of the CEP market, presenting a very wide range of activities in the area of CSR. These entities, through their "good practices", show that CSR is not to be an additional activity, running alongside the mainstream of undertaken activities, the aim of which will only be to build an image on the basis of, for example, financing of charity campaigns or participation in undertakings defending the natural environment. Such a CSR approach would be too limited and would not reflect its main purpose. It should be emphasized that social responsibility is not a matter of an additional item in the costs incurred for the benefit of the environment or the local community. CSR principles should be inextricably interwoven with the company's basic activity, and are to be a way to conduct it. Therefore, a model was presented to strengthen CSR activities in the field of maritime freight for entities of the CEP market, which are only shaping their activity in the area of CSR.

\section{References}

1. M. Popowska, CSR a zarządzanie wiekiem w przedsiębiorstwie, „Przedsiębiorstwo we współczesnej gospodarce - teoria i praktyka”, 3, 29, Wyd. Politechniki Gdańskiej (2012)

2. R.W Ackerman,., R.A Bauer,. Corporate Social Responsiveness, Reston VA: Reston Publishing Company (1976)

3. R.E. Freeman, Strategic management - A stakeholder approach, Marshfield, MA: Pitman Publishing (1984)

4. W. C. Frederick, From CSR1 to CSR2: The maturing of business and society though', Business \& Society, 33(2), 150-164 (1994) 
5. A. Lindgreen, V. Swaen, Corporate Citizenship: Let not Relationship Marketing Escape the Management Toolbox, Corporate Reputation Review 7(4), 346-363 (2004)

6. S. Young, Etyczny kapitalizm. Jak na powrót połączyć prywatny interes z dobrem publicznym, Metamorfoza (2005)

7. A. Budziewicz-Guźlecka, A. Drab-Kurowska,. Zarządzanie wiedzą w dobie nowej gospodarki. ZN US, EPU 35, 39-51 (2009)

8. W. Visser, The Age of Responsibility: CSR 2.0 and the New DNA of Business. Journal of Business Systems, Governance and Ethics, 5 (3) (2010)

9. K. Turoń, P. Czech,. Doskonalenie funkcjonowania przedsiębiorstwa poprzez społeczna odpowiedzialność biznesu na przyktadzie firm branży Transport-SpedycjaLogistyka. Rynek-Społeczeństwo-Kultura, nr 1(23) (2017)

10. C. Reverte, Determinants of corporate social responsibility disclosure ratings by Spanish listed firms. JBE, 88(2), 351-366 (2009)

11. L. Preuss), The Green Multipler, Polgrave Macmillan (2005)

12. A. Glavas, K. Kelley, The effects of perceived corporate social responsibility on employees. Bus. Ethics Q. 24, 165-202 (2014)

13. W.Y Yap., J.S.L Lam., 80 million-twenty-foot-equivalent-unit container port Sustainability issues in port and coastal development, 71, 13-25, O \& CM (2013)

14. J. Burnewicz, Prognozy zapotrzebowania na ustugi transportowe w Polsce do 2020 roku [in] Uwarunkowania systemu transportowego Polski. Red. B. Liberadzki, L. Mindur, ITE, 132 (2007)

15. T. Nowosielski Determinanty rozwoju kontenerowej żeglugi morskiej, , ZN UG. Si M ITiHM, 9, 51-71 (2012)

16. (http://www.dpdhl.com/en/responsibility/ environmental-protection.html).

17. (http://www.dhl.com/en/about_us/logistics_insights/dhl_trend_research/trendradar.htm 1\#.WrwjUNRuaG4) 